\title{
HUBUNGAN ANTARA FAKTOR PENGETAHUAN DAN KEFAHAMAN MATA PELAJARAN BAHASA MELAYU (BM) TERHADAP STANDARD KOMPETENSI DOMAIN DIRI, PROFESION DAN SOSIAL DALAM KALANGAN PEGAWAI SISC+ BM
}

\section{(THE RELATIONSHIP BETWEEN KNOWLEDGE AND UNDERSTANDING FACTOR OF SISC+MALAY LANGUAGE OFFICERS AND COMPETENCY STANDARDS IN PERSONAL, PROFESSION AND SOCIAL DOMAINS)}

\author{
Rozita Radhiah Said*, Azhar Md. Sabil and Abdul Rasid Jamian \\ Department of Languange and Humanities Education, Faculty of Education, \\ Universiti Putra Malaysia, 43400 UPM Serdang, Selangor, Malaysia \\ *Corrresponding author: radhiahrozita@upm.edu.my
}

Publication date: 24 December 2019

To cite this article: Rozita Radhiah Said, Azhar Md. Sabil, \& Abdul Rasid Jamian. (2019). Hubungan antara faktor pengetahuan dan kefahaman Bahasa Melayu (BM) terhadap standard kompetensi domain diri, profesion dan sosial dalam kalangan pegawai SISC+ BM. Asia Pacific Journal of Educators and Education, 34, 49-63. https://doi.org/10.21315/ apjee2019.34.3

To link to this article: https://doi.org/10.21315/apjee2019.34.3

\begin{abstract}
The descriptive survey research was conducted to identify the level and the relationship between knowledge and understanding among the officers of School Improvement Specialist Coaches (SISC $+\mathrm{BM}$ ), and the competency in personal, profession and social domains. The population was selected using purposive sampling, which involved 180 out of 360 employees who were SISC+ BM officers at 180 district education offices throughout Malaysia. This study used a questionnaire as the instrument. The statements in the questionnaire were constructed based on Standard 2 (Knowledge and Understanding) of the Malaysian Teacher Standards Model and the Malay Language curriculum of Form One to Form Five. A five-point Likert scale was developed to represent the participants' intensity of agreement over the topic by responding to a series of statements. Statistical analysis of data showed the percentage, standard deviation and mean score, and described the relationship based on Pearson correlation statistics. The findings revealed that the mean score of the level of knowledge and understanding of subject content $(\mathrm{M}=4.49, \mathrm{SD}=$
\end{abstract}

(C) Penerbit Universiti Sains Malaysia, 2019. This work is licensed under the terms of the Creative Commons Attribution (CC BY) (http://creativecommons.org/licenses/by/4.0/). 
0.41) among SISC + BM officers in Malaysia was at a high level. Meanwhile, there was a large relationship between the three domains $(r=.153)$. Statistical data also proved that there was a significant relationship between the knowledge and understanding of Malay language subject content among the SISC+ BM officers, and the competency in three main domains in Standard 2, namely personal, profession and social domains $(r(153)=0.595$; $p=0.01)$. Further studies in this area should be carried out to strengthen the role and responsibility of the SISC + BM officers who are accountable in guiding and determining the quality of the Malay language teachers in Malaysia.

Keywords: understanding the subject content, competency standards, Malay language, personal, profession and social domains, SISC+ BM

\begin{abstract}
Abstrak: Kajian ini dijalankan untuk mengenal pasti hubungan antara faktor pengetahuan dan kefahaman mata pelajaran Bahasa Melayu terhadap kompetensi domain diri, profesion dan sosial dalam kalangan Pegawai Pakar Pembangunan Sekolah (SISC+ BM). Populasi kajian dipilih secara persampelan bertujuan, iaitu melibatkan 180 daripada 360 orang pegawai SISC+ BM yang berada di 180 Pejabat Pendidikan daerah di seluruh Malaysia. Kajian ini menggunakan borang soal-selidik sebagai instrumen. Kenyataan dalam pembinaan soal selidik adalah berdasarkan kepada Standard 2 (Pengetahuan dan Kefahaman) Model Standard Guru Malaysia dan Sukatan Pelajaran dalam kurikulum mata pelajaran Bahasa Melayu Tingkatan Satu sehingga Tingkatan Lima, Kementerian Pendidikan Malaysia. Skala Likert 5 tahap persetujuan dibangunkan bagi mewakilkan diri peserta dengan memberi respons bagi satu siri kenyataan tentang tahap persetujuan mereka. Analisis data statistik dijelaskan melalui peratusan, sisihan piawai dan skor min. Dapatan kajian menunjukkan min purata tahap pengetahuan dan kefahaman isi kandungan mata pelajaran $(\mathrm{M}=4.49, \mathrm{SP}=0.41)$ pegawai $\mathrm{SISC}+\mathrm{BM}$ di Malaysia berada pada tahap tinggi. Statistik kolerasi Pearson menunjukkan terdapat hubungan yang besar antara ketiga-tiga domain, iaitu $(r=.153)$. Data statistik turut membuktikan terdapat hubungan baik yang signifikan antara pengetahuan dengan pemahaman isi kandungan mata pelajaran $\mathrm{BM}$ pegawai SISC $+\mathrm{BM}$ terhadap ketiga-tiga domain dalam Standard 2, iaitu kompetensi domain diri, profesion dan sosial masing-masing $(r(153)=0.595 ; p=0.01)$. Ini bermakna semakin tinggi tahap pengetahuan dan kefahaman SISC $+\mathrm{BM}$ maka semakin tinggi kompetensi domain diri, profesion dan sosial masing-masing. Kajian lanjut berkaitan bidang kepakaran SISC+ ini perlu diteruskan bagi memastikan ilmu pengetahuan, peranan serta kepakaran mereka disebar luas dan dimanfaat semaksimumnya demi kualiti guru Bahasa Melayu di Malaysia.
\end{abstract}

Kata kunci: pemahaman isi pelajaran, standard kompetensi, Bahasa Melayu, domain diri, profesion dan sosial, SISC+ BM 


\section{PENGENALAN}

Membangunkan satu sistem pembangunan profesional dengan mewujudkan pegawai berkepakaran bidang, khususnya bagi mata pelajaran Bahasa Melayu (BM) dalam kalangan pendidik untuk tujuan pendidikan bukanlah satu usaha yang boleh dipandang ringan. Pada abad ini, pengaruh guru di dalam bilik darjah terhadap murid telah digantikan dengan tarikan pelbagai alat berteknologi tinggi yang terdapat dengan mudahnya di pasaran. Lambakan maklumat pada era digitalisasi sekarang perlu diseimbangkan dengan nilai hidup generasi baharu dan cara terbaik membentuk mereka ialah melalui acuan pendidikan. Justeru, demi menyahut cara belajar-mengajar pada abad ini, Kementerian Pendidikan Malaysia (KPM) telah mengambil langkah bijak melantik lebih 1,000 Pegawai Pakar Pembangunan Sekolah (School Improvement Specialist Coaches, SISC + ) yang kini berada di 180 Pejabat Pendidikan Daerah (PDD) di seluruh negara. Hal ini bukan sahaja dapat memperkasa peranan Pejabat Pendidikan Daerah sekaligus memantapkan kerja buat guru di dalam bilik darjah. Usaha yang berterusan dengan pembangunan tenaga pakar yang terlatih bagi tujuan peningkatan kualiti guru sudah tentu akan menjadi pemangkin kepada penambahbaikan sistem pendidikan negara. Juga bagi memastikan sistem pendidikan kekal relevan, berkesan dan bermakna.

Bahagian Pengurusan Sekolah Harian (BPSH), KPM selaku peneraju Program Transformasi Daerah (PTD) melalui Buku Panduan Pengurusan Program Transformasi Daerah Edisi 3.0 (Kementerian Pendidikan Malaysia, 2015) telah menggariskan beberapa inisiatif bagi mengupaya dan memantapkan fungsi SISC+ bagi memberi sokongan dalam aspek pembangunan profesionalismekepada sekolah dan guru. Maka untuk memenuhi tuntutan transformasi ini, satu kajian tinjauan bertujuan untuk mengenal pasti tahap dan hubungan antara faktor pengetahuan dan kefahaman isi kandungan mata pelajaran dalam kalangan pegawai SISC+ BM terhadap standard kompetensi domain diri, profesion dan sosial cuba dikenal pasti. Hal ini penting memandangkan SISC+ BM merupakan agen rasmi yang dilantik oleh BPSH di KPM ke lapangan membantu merealisasikan hasrat PTD. Kemajuan pendidikan bergantung kepada keberkesanan sekolah manakala kemajuan sekolah pula bergantung kepada kualiti guru-gurunya. Kedua-dua elemen ini bersifat saling melengkapi bagi memastikan keberkesanan sekolah menerusi pemboleh ubah proses belajar-mengajar. Pelaksanaan program bimbingan dan pementoran pegawai pakar mata pelajaran (SISC + BM) ini kepada guru-guru diharap dapat membantu peningkatan kecemerlangan murid dengan mengambil kira konteks PPD setempat. 


\section{PERNYATAAN MASALAH}

Kajian kualiti terhadap pengajaran guru yang dijalankan oleh Akademi Kepimpinan Pengajian Tinggi (AKEPT) pada tahun 2011 melaporkan, sejumlah $38 \%$ daripada pemerhatian 125 pengajaran guru di 41 sekolah di seluruh Malaysia mencapai standard memuaskan dan sejumlah 50\% lagi tidak disampaikan dengan memuaskan (Shamilati, Rahimah, \& Wan Mazwati, 2017). Keadaan ini agak merisaukan. Begitu juga dengan trend pencapaian peperiksaan awam yang menunjukkan pencapaian mata pelajaran Bahasa Melayu berdasarkan peperiksaan Ujian Penilaian Sekolah Rendah (UPSR) (Kementerian Pendidikan Malaysia, 2012-2016) bagi kategori Cemerlang A, mata pelajaran Bahasa Melayu (Pemahaman dan Penulisan) menunjukkan trend meningkat pada tahun 2012-2015 namun peratusannya menurun secara mendadak pada tahun 2016. Pencapaian Gred Purata Mata Pelajaran (GPMP) bagi mata pelajaran Bahasa Melayu UPSR itu turut mencatatkan GPMP terendah $(1.79-2.55 ; 1.84-2.66)$ berbanding mata pelajaran Matematik dan Bahasa Inggeris pada tempoh yang sama. Begitu juga trend bagi pencapaian mata pelajaran Bahasa Melayu Sijil Pelajaran Malaysia (SPM) bagi kategori Cemerlang A menunjukkan trend menurun bagi tahun 20122016 (Bahagian Pengurusan Sekolah Harian, Kementerian Pendidikan Malaysia, 2015).

Keadaan ini agak meresahkan apatah lagi apabila daripada sejumlah 30,564 pengajaran guru yang dicerap oleh Jemaah Nazir dan Jaminan Kualiti (JNJK) dalam tempoh tiga tahun sehingga 2013 mencatatkan 82.59\% daripada jumlah pengajaran guru yang diperhatikan berada pada tahap harapan, memuaskan, lemah dan sangat lemah. Justeru, tertulis di dalam Gelombang 1 PPPM 20122015 (Kementerian Pendidikan Malaysia, 2013) penetapan semula peranan PPD dan Jabatan Pendidikan Negeri (JPN) di seluruh negara yang antara lain ialah mempercepat peningkatan prestasi sekolah melalui inisiatif peringkat daerah yang lebih sistematik. KPM telah mewujudkan jawatan Pegawai Pakar Peningkatan Sekolah (SISC + ) dengan sokongan penuh di PPD untuk memacu peningkatan prestasi sekolah melalui PPD masing-masing.

\section{OBJEKTIF KAJIAN}

Secara umum, kajian ini bertujuan untuk mengenal pasti tahap dan hubungan antara faktor pengetahuan dengan kefahaman isi kandungan mata pelajaran dalam kalangan pegawai SISC+ BM terhadap domain diri, profesion dan sosial. Manakala, objektif khusus adalah seperti yang berikut: 
1. Apakah tahap pengetahuan dan kefahaman isi kandungan mata pelajaran oleh pegawai $\mathrm{SISC}+\mathrm{BM}$ ?

2. Apakah hubungan antara faktor pengetahuan dan kefahaman mata pelajaran Bahasa Melayu terhadap standard kompetensi domain diri, profesion dan sosial dalam kalangan pegawai SISC+ BM?

3. Apakah hubungan antara pengetahuan dan kefahaman pegawai SISC+BM terhadap isi kandungan mata pelajaran dengan standard kompetensi domain diri, domain profesion dan domain sosial?

$\mathrm{H}_{1}$ : Wujud hubungan yang signifikan antara faktor pengetahuan dan kefahaman isi kandungan mata pelajaran dalam kalangan pegawai SISC + BM terhadap standard kompetensi domain diri, profesion dan sosial masing-masing.

$\mathrm{H}_{\mathrm{a} 1}$ : Wujud hubungan yang signifikan antara faktor pengetahuan dan kefahaman isi kandungan mata pelajaran dalam kalangan pegawai SISC+ BM terhadap standard kompetensi domain diri.

$\mathrm{H}_{\mathrm{a} 2}$ : Wujud hubungan yang signifikan antara faktor pengetahuan dan kefahaman isi kandungan mata pelajaran dalam kalangan pegawai $\mathrm{SISC}+\mathrm{BM}$ terhadap standard kompetensi profesion.

$\mathrm{H}_{\mathrm{a} 3}$ : Wujud hubungan yang signifikan antara faktor pengetahuan dan kefahaman isi kandungan mata pelajaran dalam kalangan pegawai SISC+ BM terhadap standard kompetensi sosial.

\section{SOROTAN KAJIAN}

Sesuatu pekerjaan akan memberi kesan sama ada secara langsung atau tidak langsung kepada unit yang lain sepertimana peranan SISC + membimbing pengajaran guru-guru di bawah bimbingan (GDB) mereka. Kepelbagaian tuntutan daripada GDB memerlukan seorang pembimbing yang berilmu pengetahuan serta berkepakaran bukan sahaja dalam bidang yang dibimbing malah terhadap diri, profesion dan sosial. Sorotan kajian berkaitan bimbingan dan pementoran dalam kerjaya mendapati bahawa guru sangat memerlukan bimbingan untuk pemantapan profesion mereka bagi satu jangka masa panjang dan berterusan. Istilah "bimbingan" (coaching) sering digunakan dalam organisasi yang menekankan produktiviti dan persaingan. Dalam konsep ini, pembimbing akan memberi fokus kepada penghasilan atau peningkatan kerja bersama-sama. Dalam keadaan ini, 
pembimbing bersama-sama dengan GDB akan berkongsi ownership. Manakala, pementoran pula memberi fokus kepada individu tertentu yang sedang dibimbing (biasanya dinamakan menti). Konsep pementoran merupakan suatu proses, iaitu seorang mentor yang mempunyai kepakaran dan kepemimpinan tinggi, mempunyai kemahiran atau kompetensi tertentu, membimbing seorang atau lebih secara terancang dan sistematik setelah menti dikenal pasti. Hal ini bertujuan untuk membangunkan keupayaan dan kompetensi seseorang melalui program yang disusun rapi oleh pihak pengurusan.

Penyelidikan yang lepas bardasarkan kajian Morzano (2003) dan Fullan dan Stiegebauer (2001) mendapati guru yang berkesan ialah guru yang mempunyai tahap komitmen dan efisien yang tinggi. Bimbingan dan pementoran yang konsisten daripada semasa ke semasa daripada pegawai SISC + yang mempunyai kekuatan daripada aspek intelektual, fizikal, mental dan sikap sangat penting bagi memastikan ciri-ciri kualiti guru abad ke-21 berada pada kedudukan sentiasa bersedia untuk membangunkan generasi kelas pertama. Di bawah inisiatif PTD, tumpuan juga diberikan kepada sekolah berprestasi rendah termasuk murid berkeperluan khusus. Semua pegawai SISC+ yang dilantik perlu membantu memacu prestasi mata pelajaran Bahasa Melayu khususnya supaya mencapai sasaran bukan sahaja daripada aspek kualiti malah juga daripada aspek ekuiti dan akses secara jelas.

Perjawatan baharu SISC+ BM diwujudkan tepat pada masanya apabila pendidik dan pendidikan memasuki millenium yang baharu. Justeru, hubungan antara faktor pengetahuan dan kefahaman mata pelajaran Bahasa Melayu terhadap kompetensi domain diri, profesion dan sosial dalam kalangan pegawai SISC + BM dilihat sebagai faktor yang boleh mempengaruhi keyakinan seseorang guru yang dibimbing oleh SISC + kepada peningkatan dalam hal belajar-mengajar seperti yang dihasratkan oleh cetakan biru (blueprint) pendidikan abad ke-21. Sokongan kepakaran bidang begini tentunya akan melonjakkan implikasi terhadap kualiti bimbingan dan pementoran itu sendiri. Pada tahun 2018, telah genap lima tahun program bimbingan dan pementoran SISC + BM dilaksanakan kepada guru sekolah yang dibimbing dalam daerah masing-masing. Demi memenuhi hasrat murni ini, kajian ini cuba meninjau sejauh mana tahap pengetahuan dan kefahaman isi kandungan mata pelajaran dalam kalangan pegawai SISC + terhadap bidang kepakarannya dan sejauh mana juga tahap personaliti diri, profesionalisme dan sosialisasi seseorang SISC + itu dikatakan memenuhi kriteria seorang pembimbing dan mentor yang kelak akan ke lapangan membimbing guru-guru di bawah bimbingannya. 


\section{METODOLOGI}

Perbincangan metodologi kajian ini melibatkan reka bentuk kajian, instrumen yang digunakan dan populasi serta persampelan kajian.

\section{Reka Bentuk Kajian}

Kajian tinjauan kolerasi deskriptif ini dijalankan untuk mengenal pasti hubungan antara faktor pengetahuan dan kefahaman isi kandungan mata pelajaran Bahasa Melayu dalam kalangan pegawai SISC+ BM terhadap standard kompetensi domain diri, domain profesion dan domain sosial masing-masing. Kajian ini menggunakan borang soal selidik sebagai instrumen. Kenyataan dan pembinaan semua item soal selidik Bahagian A dan B dalam kajian ini disesuaikan untuk guru mata pelajaran Bahasa Melayu dengan merujuk kepada Standard 2 (Pengetahuan dan Kefahaman) Model Standard Guru Malaysia, Kementerian Pendidikan Malaysia (2009). Kajian ini juga turut mengambil kira permasalahan dan sorotan kajian Kemahiran Belajar Abad 21, Pelan Pembangunan Pendidikan Malaysia (PPPM), Kementerian Pendidikan Malaysia. Skala Likert 5 tahap dibangunkan bagi mewakilkan peserta dengan memberi respons bagi satu siri kenyataan tentang tahap persetujuan mereka.

Berdasarkan Jadual 1, set soal selidik yang dibina dibahagikan kepada dua bahagian, iaitu Bahagian A dan Bahagian B. Sebanyak 176 soalan telah dibentuk mewakili kedua-dua bahagian. Sebanyak 55 item telah dibina untuk Bahagian A, manakala, sebanyak 121 item telah dibina untuk Bahagian B, iaitu berdasarkan Standard 2 (Pengetahuan dan Kefahaman) guru. Berdasarkan hasil analisis yang diperolehi menerusi kajian rintis ke atas 30 orang SISC+ BM, ujian Alpha Croncbach yang dijalankan bagi konstruk Bahagian A (0.929) dan konstruk Bahagian B (0.667).

Terdapat tiga objektif yang ingin dicapai melalui kajian ini. Objektif pertama dicapai melalui soal selidik Bahagian A yang dianalisis secara deskriptif. Analisis data diperolehi daripada borang soal selidik yang mengandungi lima konstruk untuk menguji tahap pengetahuan dan kefahaman. Dapatan kajian ini dianalisis berdasarkan statistik deskriptif skor min. Penentuan tahap analisis deskriptif dalam kajian ini menggunakan jadual intepretasi skor min tahap pengetahuan yang telah dirumuskan oleh Pallant (2013). Nilai min setiap item diukur berdasarkan jadual intepretasi skor min. 
Jadual 1. Instrumen Kajian

\begin{tabular}{|c|c|c|c|c|}
\hline $\begin{array}{l}\text { Soal } \\
\text { selidik }\end{array}$ & $\begin{array}{l}\text { Komponen/ } \\
\text { konstruk }\end{array}$ & Bilangan item & Statistik & Rujukan sumber \\
\hline \multirow[t]{6}{*}{$\begin{array}{l}\text { Bahagian } \\
\text { A }\end{array}$} & $\begin{array}{l}\text { Pengetahuan dan } \\
\text { kefahaman Pegawai } \\
\text { SISC+ BM terhadap } \\
\text { isi kandungan mata } \\
\text { pelajaran Bahasa } \\
\text { Melayu }\end{array}$ & $\begin{array}{l}55 \text { item } \\
\text { Cronbach's } \\
\text { Alpha }= \\
0.929\end{array}$ & \multirow[t]{6}{*}{$\begin{array}{l}\text { kekerapan, } \\
\text { peratusan, } \\
\text { sisihan piawai } \\
\text { dan skor min } \\
\text { berdasarkan } \\
\text { Pallant (2013) }\end{array}$} & \multirow{6}{*}{$\begin{array}{l}\text { Elemen-elemen yang } \\
\text { terkandung dalam } \\
\text { Dokumen Rasmi KPM } \\
\text { iaitu Kemahiran Abad } \\
\text { 21: PPPM 2013-2025 } \\
\text { (Kementerian } \\
\text { Pendidikan Malaysia, } \\
\text { 2013), Sukatan Bahasa } \\
\text { Melayu Sekolah } \\
\text { Menengah dan Huraian } \\
\text { Sukatan Pelajaran } \\
\text { KBSM (Kementerian } \\
\text { Pendidikan Malaysia, } \\
\text { 2012) dan KSSM, } \\
\text { Pusat Perkembangan } \\
\text { Kurikulum } \\
\text { (Kementerian } \\
\text { Pendidikan Malaysia, } \\
\text { 2017) }\end{array}$} \\
\hline & $\begin{array}{l}\text { Falsafah Pengajaran } \\
\text { Bahasa (10 item) }\end{array}$ & Soalan $1-10$ & & \\
\hline & $\begin{array}{l}\text { Pengisian } \\
\text { Kurikulum Bahasa } \\
\text { (10 item) }\end{array}$ & Soalan 11-20 & & \\
\hline & $\begin{array}{l}\text { Objektif Kurikulum } \\
\text { Bahasa (6 item) }\end{array}$ & Soalan $21-26$ & & \\
\hline & $\begin{array}{l}\text { Strategi Pengajaran } \\
\& \text { Pembelajaran } \\
\text { Bahasa (9 item) }\end{array}$ & Soalan $27-35$ & & \\
\hline & $\begin{array}{l}\text { Hasil Pembelajaran } \\
\text { Bahasa dan } \\
\text { Pentaksiran \& } \\
\text { Penilaian Bahasa } \\
(20 \text { item) }\end{array}$ & Soalan 36-55 & & \\
\hline \multirow{5}{*}{$\begin{array}{l}\text { Bahagian } \\
\text { B }\end{array}$} & Standard & 121 item & Kolerasi Pearson & \multirow{5}{*}{$\begin{array}{l}\text { Standard } 2 \\
\text { (Pengetahuan } \\
\text { dan Kefahaman) } \\
\text { Model Standard } \\
\text { Guru Malaysia, } \\
\text { KPM (Kementerian } \\
\text { Pendidikan Malaysia, } \\
\text { 2009) }\end{array}$} \\
\hline & $\begin{array}{l}\text { kompetensi } \\
\text { Pegawai SISC+BM } \\
\text { terhadap: }\end{array}$ & $\begin{array}{l}\text { Cronbach's } \\
\text { Alpha = } \\
0.667\end{array}$ & \multirow[t]{4}{*}{ Product-Moment } & \\
\hline & $\begin{array}{l}\text { Domain diri ( } 74 \\
\text { item) }\end{array}$ & Soalan 1-74 & & \\
\hline & $\begin{array}{l}\text { Domain Profesion } \\
(27 \text { item })\end{array}$ & $\begin{array}{l}\text { Soalan } \\
75-101\end{array}$ & & \\
\hline & $\begin{array}{l}\text { Domain Sosial ( } 20 \\
\text { item) }\end{array}$ & $\begin{array}{l}\text { Soalan } \\
102-121\end{array}$ & & \\
\hline
\end{tabular}

Jadual 2. Intepretasi skor min untuk skala Likert lima tahap

\begin{tabular}{ll}
\hline Skor Min & Tahap \\
\hline $1.00-2.33$ & Rendah \\
$2.34-3.67$ & Sederhana \\
$3.68-5.00$ & Tinggi \\
\hline
\end{tabular}

Sumber: Pallant (2013) 
Manakala, objektif kedua dicapai melalui soal selidik Bahagian B dan objektif ketiga dicapai melalui kedua-dua bahagian A dan B. Analisis inferens, iaitu Korelasi Pearson Product-Moment (kedua-dua variabel berskala interval) digunakan untuk menjawab objektif kedua dan ketiga.

\section{Populasi dan Persampelan Kajian}

Daripada jumlah semua 360 orang populasi SISC+ BM yang berada di 180 PPD di seluruh negara, hanya seorang sahaja SISC+ BM mewakili setiap PPD diminta menjawab soal selidik kajian ini. Daripada jumlah 180 orang SISC+ BM yang berada di 180 buah PPD negeri masing-masing, 30 orang dipilih secara rawak untuk dijadikan respondan kajian rintis. Persampelan atau saiz sampel untuk menjalankan kajian rintis adalah berdasarkan kepada formula saiz sampel Cochran (1977). Dapatan analisis nilai pekali Cronbach Alpha melebihi 0.80. Ini menunjukkan bahawa instrumen yang dibangunkan adalah ideal dan sesuai digunakan dalam kajian. Baki responden terdiri daripada pegawai SISC+ BM di 150 buah PPD di semenanjung Malaysia, Sabah dan Sarawak serta Wilayah Persekutuan Putrajaya dan Labuan. Semua 150 orang pegawai mengembalikan borang soal selidik.

\section{DAPATAN KAJIAN}

Dapatan kajian dimulai dengan menjawab Objektif 1 iaitu "mengenal pasti tahap pengetahuan dan kefahaman isi kandungan mata pelajaran Bahasa Melayu oleh pegawai SISC+ BM". Dapatan dalam Jadual 3 menunjukkan nilai tahap pengetahuan dan kefahaman pegawai pakar berada pada tahap tinggi.

Dapatan menunjukkan bahawa semua SISC+ BM di Malaysia mencapai kompetensi berdasarkan Standard 2 iaitu pada tahap tinggi. Perincian kompetensi ilmu pengetahuan dan kefahaman dalam soal selidik adalah berkaitan tentang kandungan subjek pengkhususan, ilmu dan falsafah pendidikan, kurikulum dan kokurikulum serta hasil pembelajaran. Bertepatan dengan perjawatan SISC+ BM sebagai pakar pembimbing pembangunan sekolah, mereka mestilah menjadi model supaya dapat membimbing serta melahirkan guru yang berkualiti dan memastikan mereka yang berkualiti kekal dalam sistem pendidikan negara serta kekal berkualiti di sepanjang tempoh perkhidmatan. Apabila SISC+ BM mempunyai ilmu pengetahuan dan pemahaman yang tinggi terhadap bidang kepakaran mereka peningkatan profesionalisme keguruan dalam melaksanakan tugas dengan cekap dan berkesan serta menjadi lebih kreatif dan inovatif akan dapat dimantapkan. 
Dapatan bagi Objektif 2 dalam Jadual 4 pula adalah untuk melihat hubungan tiga domain iaitu standard kompetensi domain diri, profesion dan sosial dalam kalangan pegawai SISC+ BM. Dapatan menunjukkan hubungan yang besar dan signifikan. Hubungan antara domain diri dengan domain profesion, iaitu $r$ (153) $=0.827, p=0.01$ manakala, hubungan domain diri dengan domain sosial adalah $r(153)=0.8 .44, p=0.01$. Ini bermakna kolerasi antara ketiga-tiga domain memberi sumbangan yang besar serta saling mempengaruhi antara satu sama lain.

Jadual 3. Analisis min tahap pengetahuan dan kefahaman SISC + terhadap isi kandungan kurikulum mata pelajaran Bahasa Melayu

\begin{tabular}{llccc}
\hline Soal Selidik & Konstruk & Min & $\begin{array}{l}\text { Sisihan } \\
\text { Piawai }\end{array}$ & Tahap \\
\hline Bahagian A & Falsafah Pengajaran Bahasa & 4.40 & .694 & Tinggi \\
& $\begin{array}{l}\text { Pengisian Kurikulum/Kokurikulum } \\
\text { Bahasa }\end{array}$ & 4.49 & .570 & Tinggi \\
& $\begin{array}{l}\text { Objektif Kurikulum Bahasa } \\
\begin{array}{l}\text { Strategi Pengajaran \& Pembelajaran } \\
\text { Bahasa }\end{array}\end{array}$ & 4.61 & .541 & Tinggi \\
$\begin{array}{l}\text { Kandungan Hasil Pembelajaran Bahasa } \\
\text { dan Pentaksiran \& Penilaian Bahasa }\end{array}$ & 4.72 & .584 & Tinggi \\
\hline
\end{tabular}

Jadual 4. Korelasi antara domain diri, domain profesion dan domain sosial

\begin{tabular}{|c|c|c|c|}
\hline Pemboleh ubah & Bhg_B_Diri & Bhg_B_Profesion & Bhg_B_Sosial \\
\hline 1. Bhg_B_Diri & & $.827 * *$ & $.844 * *$ \\
\hline 2. Bhg_B_Profesion & & & $.859 * *$ \\
\hline 3. Bhg_B_Sosial & & & \\
\hline
\end{tabular}

Nota: $* * p<0.01$; BHG_B_Diri $=$ Domain Diri, BHG_B_Profesion $=$ Domain Profesion, BHG_B_Sosial $=$ Domain Sosial.

Kekuatan korelasi mengikut Cohen (1988) dinyatakan seperti yang berikut:

Petunjuk skala:

$r= \pm 0.10$ hingga 0.29 (kecil/rendah)

$r= \pm 0.30$ hingga 0.49 (sederhana)

$r= \pm 0.50$ hingga 1.00 (besar/tinggi) 
Jadual 5 menunjukkan dapatan bagi Objektif 3 iaitu hubungan antara pemboleh ubah Bahagian A dan Bahagian B yang diuji berada pada tahap tinggi. Ini bermakna, hubungan antara pengetahuan dengan pemahaman pegawai SISC+ BM terhadap isi kandungan mata pelajaran terhadap standard kompetensi domain diri, profesion dan sosial masing-masing adalah $r(153)=0.595 ; p=0.01$.

Jadual 5. Korelasi antara pengetahuan dan kefahaman pegawai SISC+ BM terhadap isi kandungan mata pelajaran dengan standard kompetensi domain diri, domain profesion dan domain sosial

\begin{tabular}{lll}
\hline Pemboleh ubah & BHG A & BHG B \\
\hline BHG A & - & $.595^{* *}$ \\
BHG B & $.595^{* *}$ & - \\
\hline
\end{tabular}

Nota: $* * p<0.01$; BHG A: Mengenal pasti faktor pengetahuan dan kefahaman isi kandungan mata pelajaran dalam kalangan pegawai SISC+ BM; BHG B: Mengenal pasti tahap dan hubungan pengetahuan dan kefahaman pegawai SISC+ BM terhadap standard kompetensi domain diri, domain profesion dan domain sosial.

Hubungan yang besar dan signifikan memberi makna bahawa ketiga-tiga domain saling memberi sumbangan serta pengaruh yang besar terhadap satu sama lain. Domain Diri merujuk kepada pegangan nilai diri yang sedia ada dan patut dikembangkan supaya SISC + BM boleh memberi sumbangan yang lebih berkesan kepada profesion keguruan bagi mencapai matlamat sistem pendidikan negara. Nilai-nilai yang difokuskan dalam domain diri ini ialah kepercayaan kepada Tuhan, amanah, ikhlas, berilmu, kasih sayang, sabar, budi bahasa, adil, bertimbang rasa, daya tahan, daya saing, dan tahan lasak, cergas, aktif dan sihat, kemahiran interpersonal dan intrapersonal, semangat sukarela, dan efisien.

Manakala Domain Profesion pula merujuk kepada pegangan nilai yang patut diamalkan secara telus oleh SISC+ BM dalam menjalankan tugasnya sebagai seorang pembimbing dan mentor yang profesional. Nilai-nilai yang ditekankan dalam domain ini adalah kecintaan terhadap profesion, berketerampilan, integriti, teladan, mengamalkan kerja sepasukan, proaktif, kreatif dan inovatif.

Akhir sekali iaitu Domain Sosial memerlukan SISC+ BM berperanan sebagai agen sosialisasi dan penjana modal insan dalam masyarakat. Nilai-nilai utama yang patut diamalkan adalah keharmonian, kemahiran sosial, semangat bermasyarakat, patriotisme dan kecintaan terhadap alam sekitar. 
Jadual 6. Rumusan dapatan kajian

\begin{tabular}{|c|c|c|}
\hline Bil. & Objektif kajian & Keputusan Analisis \\
\hline 1. & $\begin{array}{l}\text { Apakah tahap pengetahuan dan kefahaman isi } \\
\text { kandungan mata pelajaran oleh pegawai SISC }+ \\
\text { BM? }\end{array}$ & $\begin{array}{l}\text { Tahap tinggi } \\
\text { Keseluruhan } \\
(\mathrm{M}=4.49, \mathrm{SP}=0.41)\end{array}$ \\
\hline 2. & $\begin{array}{l}\text { Apakah tahap dan hubungan ketiga-tiga domain } \\
\text { terhadap pengetahuan dan kefahaman isi } \\
\text { kandungan mata pelajaran pegawai SISC+ BM? }\end{array}$ & $\begin{array}{l}\text { Tahap Tinggi } \\
(\mathrm{M}=9.49 ; \mathrm{SP}=0.787) . \\
\text { Hubungan besar dan signifikan } \\
r(153)=.859, p=0.01\end{array}$ \\
\hline 3. & $\begin{array}{l}\mathrm{H}_{1} \text { : } \\
\text { Wujud hubungan yang signifikan antara faktor } \\
\text { pengetahuan dan kefahaman isi kandungan } \\
\text { mata pelajaran dalam kalangan pegawai SISC }+ \\
\text { BM terhadap standard kompetensi domain diri, } \\
\text { profesion dan sosial masing-masing? } \\
\mathrm{H}_{\mathrm{a}} \text { : Wujud hubungan yang signifikan antara } \\
\text { faktor pengetahuan dan kefahaman isi kandungan } \\
\text { mata pelajaran dalam kalangan pegawai SISC+ } \\
\mathrm{BM} \text { terhadap standard kompetensi domain diri. } \\
\mathrm{H}_{\mathrm{a} 2} \text { : Wujud hubungan yang signifikan antara } \\
\text { faktor pengetahuan dan kefahaman isi kandungan } \\
\text { mata pelajaran dalam kalangan pegawai SISC }+ \\
\mathrm{BM} \text { terhadap standard kompetensi profesion. } \\
\mathrm{H}_{\mathrm{a} 3} \text { : Wujud hubungan yang signifikan antara } \\
\text { faktor pengetahuan dan kefahaman isi kandungan } \\
\text { mata pelajaran dalam kalangan pegawai SISC+ } \\
\text { BM terhadap standard kompetensi sosial. }\end{array}$ & $\begin{array}{l}\text { Signifikan dan diterima } \\
\text { pada } * * p<0.01 \\
\text { Signifikan dan diterima } \\
\text { pada } * * p<0.01 \\
\text { Signifikan dan diiterima } \\
\text { pada } * * p<0.01\end{array}$ \\
\hline
\end{tabular}

\section{PERBINCANGAN DAN CADANGAN}

Kajian dengan jelas menunjukkan semakin tinggi tahap pemahaman dan pengetahuan SISC+ BM terhadap bidang kepakarannya maka semakin tinggi tahap kompetensi terhadap diri, profesionalisme dan sosial masing-masing. Menurut Laporan Akhir Kajian Impak Pementoran Kementerian Pengajian Tinggi (KPT) pada tahun 2015 hingga 2018 yang telah dilaksanakan oleh Performance and Delivery Unit (PADU), KPM mendapati purata 91.2\% peserta mentor dan menti telah mendapat faedah daripada program yang telah dilaksanakan. Dengan tahap pengetahuan dan kefahaman terhadap pelaksanaan pengajaran dan pembelajaran Bahasa Melayu yang tinggi dalam kalangan SISC+ BM serta hubungan standard kompetensi dalam ketiga-tiga domain yang besar dan signifikan, maka tujuan bimbingan dan pementoran memenuhi keperluan guru yang dibimbing khususnya ke arah pemantapan proses pengajaran dan pembelajaran di dalam bilik darjah. 
Justeru, pengetahuan dan kefahaman serta kepakaran terhadap amalan Pengajaran dan Pembelajaran (P \& P) mereka patut dicontohi, disebar luas serta dimanfaatkan.

Kompetensi domain profesion menunjukkan skor min paling tinggi $\mathrm{M}=4.70$ dan sisihan piawai $\mathrm{SP}=.349$ diikuti oleh kompetensi domain sosial $\mathrm{M}=4.66$ dan sisihan piawai $\mathrm{SP}=.354$ dan kompetensi domain diri menunjukkan $\mathrm{M}=4.60$ dan sisihan piawai $\mathrm{SP}=.301$. Dapatan ini jelas menunjukkan bahawa pegawai SISC+ mendahulukan tanggungjawab profesionalisme mendahului kepentingan sosial dan kepentingan diri sendiri. Kompetensi domain profesion memerlukan pegawai yang sentiasa mempertahankan nama baik profesion dan menjadikan profesion keguruan sebagai hala tuju kehidupan. Mereka juga mestilah bersedia berkorban masa, tenaga, bekerja dengan penuh dedikasi. Secara tegasnya mereka juga perlu mempamerkan kekemasan diri, boleh menyesuaikan diri dalam pelbagai keadaan, berpengetahuan luas, menguasai kemahiran dalam bidang kepakaran, sentiasa bersedia menggembleng kekuatan rakan sepasukan untuk mencapai objektif organisasi. Kesediaan pegawai menyesuaikan diri dengan rakan sepasukan, komited dalam menjayakan aktiviti organisasi, bertindak bersama-sama dalam menangani masalah ialah satu bonus yang menguatkan pengaruh dan kepercayaan mente kepada bimbingan mereka. Dalam masa yang sama domain profesion menghargai pegawai yang berada di bawah bimbingannya malah sentiasa mengenal pasti peluang untuk mereka meningkatkan pencapaian organisasi bersama-sama. Mereka juga bertanggungjawab sepenuhnya atas setiap tindakan dan berani mengambil risiko yang positif. Domain kompetensi sosial melengkapkan lagi ciri-ciri kualiti seseorang pegawai SISC + apabila seseorang pembimbing itu mudah serasi dan boleh bertolerensi terhadap perbezaan. Kejayaan bimbingan dan pementoran dapat mencapai tahap maksimum apabila pegawai $\mathrm{SISC}+$ dan GDB sentiasa menunjukkan tingkah laku yang sesuai dalam semua situasi, boleh membuat keputusan berdasarkan persetujuan bersama-sama, mengamalkan pemuafakatan serta sentiasa memupuk semangat kenegaraan. Keadaan ini secara tidak langsung mempamerkan kompetensi kecerdasan emosi kendiri bersesuaian dengan profesion mereka ceburi.

Kompetensi domain diri pegawai SISC + BM juga perlu berada pada tahap yang tinggi. Apatah lagi jika mereka perlu mendapatkan kepercayaan daripada GDB sepanjang proses bimbingan dan pementoran berlangsung. Kompetansi diri merujuk kepada Standard 2 (Pengetahuan dan Kefahaman) Model Standard Guru Malaysia, Kementerian Pendidikan Guru Malaysia (2009) antara lain menggariskan bahawa seseorang pegawai yang dilantik perlu berpegang kepada agama yang akhirnya membentuk keperibadian diri. Dengan agama, hidup menjadi berdisiplin, tenang, seterusnya bersikap terbuka serta berlapang dada untuk menerapkan nilai-nilai universal dalam pengajaran, bertanggungjawab dan berakauntabiliti. Selain itu, 
pegawai SISC+ perlu menggunakan sumber, masa, kuasa, waktu secara jujur dan dedikasi. Mereka juga perlu sentiasa mencari peluang meningkatkan kecekapan diri, melibatkan diri dengan aktiviti keilmuan dengan aktif, bersikap proaktif dan kerap menganjurkan bengkel-bengkel dan ceramah untuk mengoptimumkan penggunaan sumber demi peningkatan pengetahuan sama ada untuk tujuan pengurusan mahupun dalam pengajaran dan pembelajaran. Mereka juga perlu mesra dan mudah didekati. Bersifat empati, menjaga maruah diri serta prihatin dalam menyelesaikan masalah murid. Di samping itu, domain diri mencadangkan supaya setiap pegawai SISC + sentiasa berusaha mencari penyelesaian secara bersistematik, menjaga tutur kata, tingkah laku, berhemah dan bersopan. Adalah penting mereka menghormati pelbagai budaya dan warisan bangsa serta bertindak secara wajar dalam apa-apa jua suasana. Ciri-ciri yang ada pada domain diri mampu menjadikan seseorang pegawai itu dikagumi dan disegani peribadinya. Hal ini memudahkan bimbingan dan pementoran dilaksanakan.

\section{KESIMPULAN}

Tanggungjawab pegawai SISC $+\mathrm{BM}$ bukanlah satu tugas yang mudah kerana untuk mengubah tingkah laku dan persepsi guru terhadap pendidik dan pendidikan memerlukan tempoh yang panjang dan usaha yang konsisten. Dengan kekuatan ketiga-tiga faktor kompetensi yang dianalisis adalah diharap kehadiran para pegawai SISC + dapat memenuhi jangkaan guru-guru mata pelajaran yang dibimbing. Memandangkan peranan SISC + sangat berfokus kepada Pengajaran dan Pembelajaran (P\&P) di dalam bilik darjah maka sudah tentu banyak ilmu pedagogi dapat dikongsi terutamanya dalam membantu menangani isu dan permasalahan pencapaian mata pelajaran. Secara makronya, kursus-kursus pembangunan profesionalism SISC + mesti dilaksanakan secara konsisten supaya ilmu mereka sentiasa lebih terkehadapan malah dapat melihat pendidikan dalam konteks yang lebih luas dan jauh. Begitu juga secara mikronya, guru-guru yang dibimbing perlu didedahkan secara konsisten dengan cara belajar-mengajar berdasarkan keperluan dan tuntutan semasa. Usaha kolaboratif dalam kalangan warga pendidik serta semua pihak yang berkepentingan jika berjaya digembleng, sudah tentulah akan berjaya mengubah (reposition) dan merekayasa (reengineer) sistem pendidikan negara supaya berkualiti dan akhirnya melahirkan modal insan yang berjaya. 


\section{RUJUKAN}

Cohen, J. (1988). Statistical power analysis for the behavioral sciences (2nd ed.). Hillsdale, NJ: Lawrence Erlbaum Associates Publishers.

Cochran, G. W. (1977). Sampling technique (3rd ed.). Canada: John Wiley \& Sons Inc.

Fullan, M. G., \& Stiegebauer, S. (2001). The new meaning of educational change. US: Teachers College Press. https://doi.org/10.4324/9780203986561

Kementerian Pendidikan Guru Malaysia. (2009). Model standard guru Malaysia. Putrajaya: Bahagian Pendidikan Guru, Kementerian Pendidikan Malaysia.

Kementerian Pendidikan Malaysia. (2012). Sukatan pelajaran Bahasa Melayu KBSM untuk sekolah menengah. Kuala Lumpur: Pusat Perkembangan Kurikulum, Kementerian Pelajaran Malaysia.

Kementerian Pendidikan Malaysia. (2013). Pelan Pembangunan Pendidikan Malaysia 2013-2025. Putrajaya: Bahagian Perancangan dan Penyelidikan Dasar Pendidikan, Kementerian Pendidikan Malaysia.

Kementerian Pendidikan Malaysia. (2015). Buku panduan program transformasi daerah edisi 3.0. Putrajaya: Kementerian Pendidikan Malaysia. Retrieved from https:// www.moe.gov.my/images/kpm/KPM/BPSH/17082017_BUKU-PANDUANPENGURUSAN-DTP3_0-EDITED-V8.pdf

Kementerian Pendidikan Malaysia. (2017). Kurikulum Standard Sekolah Menengah (KSSM). Kuala Lumpur: Pusat Perkembangan Kurikulum, Kementerian Pelajaran Malaysia.

Morzano, R. J. (2003). What works in school: Translating research into action. Alexandria, VA: Association for Supervision and Curriculum Development (ASCD).

Pallant, J. (2013). SPSS survival manual: A step by step guide to data analysis using SPSS. New York: McGraw-Hill International.

Shamilati Che Seman, Rahimah Embong, \& Wan Mazwati Wan Yusoff. (2017). Tingkah laku guru dalam membangunkan kemahiran berfikir aras tinggi di sekolah rendah. Retrieved 1 November 2019, from https://www.academia.edu/39662687/ TINGKAH_LAKU_GURU_DALAM_MEMBANGUNKAN_KEMAHIRAN_ BERFIKIR_ARAS_TINGGI_DI_SEKŌLAH_RENDAH 